\title{
Corporate Governance of SOEs and Performance in Transition Countries. Evidence from Lithuania
}

\author{
Claudia Curi ${ }^{*}$, Justas Gedvilas ${ }^{2}$, Ana Lozano-Vivas ${ }^{3}$ \\ ${ }^{1}$ Faculty of Economics and Management, Free University of Bozen-Bolzano, Bozen-Bolzano, Italy \\ ${ }^{2}$ Independent, Vilnius, Lithuania \\ ${ }^{3}$ University of Málaga, Málaga, Spain \\ Email: *claudia.curi@unibz.it
}

How to cite this paper: Curi, C., Gedvilas, J. and Lozano-Vivas, A. (2016) Corporate Governance of SOEs and Performance in Transition Countries. Evidence from $\mathrm{Li}$ thuania. Modern Economy, 7, 1339-1360. http://dx.doi.org/10.4236/me.2016.712126

Received: September 20, 2016

Accepted: October 28, 2016

Published: November 1, 2016

Copyright $\odot 2016$ by authors and Scientific Research Publishing Inc. This work is licensed under the Creative Commons Attribution International License (CC BY 4.0). http://creativecommons.org/licenses/by/4.0/ (c) (i) Open Access

\begin{abstract}
This paper investigates whether and to what extent corporate governance mechanisms affect the efficiency of State Owned Enterprises (SOEs) operating in transition economies. Furthermore, it examines the relationship between corporate governance practice and its impact on both wholly state run SOEs and majority state run SOEs. We employed a unique dataset of corporate governance ratings (related to quality of transparency, quality of board, and quality of strategic planning, implementation and control) of commercial Lithuanian SOEs relating to the period following the introduction of the corporate governance reforms in the years 2012-2013. In order to investigate our research hypotheses, we set up a two-stage empirical research strategy that combined a non-parametric efficiency estimator (i.e., Data Envelopment Analysis) with a bootstrapped truncated regression. We built two aggregate indexes of corporate governance ratings to represent one dimension of corporate governance quality. We then ran a battery of regressions using both the aggregated and the single corporate governance indexes as independent variables. First, the paper finds that the wholly state ownership model of SOEs is positively correlated to efficiency (i.e., wholly SOEs are more efficient than majority SOEs). Moreover, overall corporate governance practices are efficiency-enhancing; more specifically, board quality and strategic planning seem to be effective internal governance mechanisms in promoting overall organizational efficiency. Interestingly, we uncovered that there exists a relationship between concentration of ownership and corporate governance practices, but this mitigated efficiency enhancement in wholly state run SOEs compared to majority state run SOEs. This effect was driven by the lower quality of the board. Overall, our findings illustrate that corporate governance reforms have enhanced efficiency, but wholly SOEs require a better implementation in order to achieve full efficiency gains.
\end{abstract}




\section{Keywords}

SOE, Corporate Governance, Transition Economy, DEA, Bootstrap

\section{Introduction}

Corporate governance has become a mainstream concern in the aftermath of the financial crisis and corporate governance scandals in the United States and Europe that triggered some of the largest insolvencies in history. As a result, numerous studies have documented that the quality of corporate governance plays an important role in achieving management excellence and company goals and exercises a positive impact on a firm's performance, asset allocation, and other efficiency improvements [1]. Good governance is a necessary condition for accomplishing economic goals regardless of the ownership structure of the firm. In 2015, the Organization for Economic Cooperation and Development (OECD) updated its Guidelines on Corporate Governance for StateOwned Enterprises (SOEs), wherein the ownership of state property is the dominant shareholding form.

Although SOEs are enterprises where the State is the exclusive or dominant owner that controls or has an influential role on the board of directors, and determines the objectives of the business according to the public interest, the OECD stated that good governance of SOEs is essential, for efficient and open markets at both the domestic and international level. In fact, this type of enterprise has a great importance in many countries, mainly emerging economies, and they have an increasingly prominent presence in international markets. Thus, ensuring that SOEs operate in a sound competitive and regulatory environment through good corporate governance is crucial to maintain an open trade and investment environment that underpins domestic and international economic growth. In this regard, the OECD in the "Guidelines on Corporate Governance of State-Owned Enterprises" argues that public ownership does not intrinsically produce inefficiency within an enterprise and that possible inefficiencies can be likely removed through reforming the way the government exercises its ownership and regulatory powers, as well as providing profit incentives.

Overall, despite seeking important social objectives, SOEs are required to work efficiently. Thus, the implementation of corporate governance mechanisms is considered as alternative reform to privatization to enhance the efficiency of the SOEs. Although the existing literature argues that, in general, higher quality corporate governance enhances firm performance, it is not clear whether SOEs with high or wholly state shareholdings can exploit the benefits of corporate governance mechanisms.

The aim of this paper is to provide empirical evidence as to the effectiveness of corporate governance mechanisms adopted by wholly and majority state-owned enterprises in emerging markets. Specifically, the paper deals with the example of Lithuania for two reasons: 1) the State controls the largest share of commercial assets in the country with a market value of 4.4 billion EUR as of 2013, and 2) Lithuanian SOEs are the most 
significant generators of economic value, and promote economic development in the country. In fact, they constitute an important source of budgetary income as well as the implementation of strategic projects.

This study contributes to the literature of corporate governance in emerging markets in several ways. First, it provides empirical evidence as to whether different forms of state ownership lead to different performance outcomes. Second, it contributes to the literature concerning the relationship between the quality of corporate governance practices (such as quality of transparency, board and strategic planning) and SOE efficiency. Lastly, we investigate the link between corporate governance-efficiency and the level of state ownership of the SOE.

The paper is structured as follows. Section 2 presents the literature review; Section 3 describes the Lithuanian setting; Section 4 explains the empirical research strategy; Section 5 discusses the empirical results and Section 6 concludes the paper with findings and recommendations.

\section{Literature Review of Corporate Governance, State Owned Enterprises and Performance}

During the last couple of decades, a large body of research has documented the importance of the quality of a corporate governance framework on firm performance, through organisational management that is more efficient, has better asset allocation, improved labour policies, and other efficiency improvements (see [1], 2013 for a complete survey). However, most of this research refers to developed countries such as the US, UK, and Japan in which private enterprises are the predominant economic actors, while less work has been done in emerging markets where SOEs represent a generous part of GDP, employment opportunities and market capitalization.

Widespread privatization programmes and market liberalization, through several reforms aimed at decentralizing and commercializing SOEs, has generated empirical literature investigating the effectiveness of corporate governance systems in transition economies [2]. Among the various corporate governance mechanisms, ownership structure change (through privatization) has been the most extensively studied [3]-[5]. Research questions have been concerned with whether private ownership leads to higher efficiencies for firms. However, the empirical evidence is far from being conclusive. One stream of literature asserts that because governments cannot play an active role in corporate governance, privatization with ownership changes are necessary for any significant performance improvement of SOEs [6]-[11]. On the other hand, another stream of literature [12]-[14] argue that less radical changes such as managerial incentive contracts, market deregulation, and internal and external government reforms can be effective substitutes to outright privatization.

In many countries, the approach used to reform SOEs has been based on the implementation of new corporate governance structures while the government remains the majority shareholder [15] [16]. In this regard, and consistent with the suggestion of [17] [18] argue that in a transitional economy with a weak legal environment, certain 
types of state ownership can play a positive role on firm performance.

Overall, the relation between government shareholding and corporate performance is still a field under investigation. Most of the studies found in the literature are oriented principally to analysing whether the firm-level variation in overall corporate governance predicts a firm's market value (governance-to-value studies) ${ }^{1}$. Focusing on emerging markets, [20] (Russia), [21] (Korea), [22] (Korea), and [23] (Russia) find a connection between the measure of firm-level governance and share price in a single country. Corresponding results are those of [24] and [25] where the examination setting is on a cross-country basis. Most of those studies used overall corporate governance indexes estimated by rating agencies such as Standard and Poor's, The Institute of Corporate Law and Governance, among others. Some studies develop unique indexes of corporate governance quality when data is not available [26] [27 $]^{2}$.

Although the implementation of corporate governance mechanisms is considered as an alternative reform to privatization to enhance the efficiency of SOEs, very few studies are available regarding this issue. While the dominant approach used by previous research is to estimate the impact on the market value of a firm, technical efficiency is also a useful measurement in a transitional context as it captures the basis of corporate governance problems, specifically the inefficient use of resources, which is usually not easily observable by outside stakeholders and governments. Thus, technical efficiency represents a good proxy to measure the quality of the management in using incentive mechanisms, such as contract, organizational designs and legislation ${ }^{3}$.

Among the few studies that analyze the relation between operating efficiency and corporate governance are those developed by [26] [27]. These authors investigate the effects of different ownership structures on the quality of corporate governance and the efficiency of the Ukrainian economy. The authors attempt to create three corporate governance indicators for Ukrainian enterprises. The first indicator proxies the level of transparency of the companies and it measures whether the firm's annual financial statements were published in the press. The second indicator mimics the possible failures in the enterprise's corporate governance system. It measures the presence of complaints (from individuals and organizations) to the Ukrainian State Commission for Securities and Stock Market against the enterprise during a three year period concerning the violations of shareholders' rights, nondisclosure of statements, and violation of proper conduct of register. The third indicator represents whether these complaints were upheld by the Commission for Securities and Stock Market. Overall, they find a negative relationship between the state-ownership and the firm-efficiency. While the

${ }^{1}$ Several papers have investigated this issue. The first study to establish a positive relation between firm vale and ownership structure is [19].

${ }^{2}$ Other studies focus on the relationship between firm performance and single aspects of corporate governance, e.g., executive compensation and CEO turnover [28] [29], block holders [30] [31], the takeover market [12], and investor protection [24] [32] [33].

${ }^{3}$ This problem is seen through [34] concept of " $\mathrm{X}$-(in) efficiency", according to which the "X-(in) efficiency" can been understood as the difference between a firm's potential and actually observed (realized) performance caused by 1) intra-plant efficiency; 2) external motivational efficiency, and 3) non-market input efficiency. 
number of complaints is found not to be statistically significant, the violation of corporate governance in relation to laws is found to increase inefficiency. Moreover, a lack of significant relationship between the transparency index and efficiency is found. Lastly, they find a scale effect having a positive effect on efficiency.

[18] find that the operating efficiency of Chinese listed companies varies across the type of controlling shareholders, and that SOEs affiliated to the central government perform better than SOEs controlled by state asset management bureaus or private controlled firms. Drawing on a large data set of Chinese public listed companies, [16] extend previous results by finding that a government shareholding can be beneficial to corporate value when the state ownership is greater than 25\%. Lastly, [11] [35] find that restructuring publicly listed Chinese SOEs via corporate governance reform improved efficiency. Specifically, ownership structure plays a dominant role in determining efficiency and state shareholding reduces greatly that efficiency. Board independence is positively related to firm efficiency while a supervisory committee plays no role in improving firm efficiency.

This paper attempts to contribute to the rather limited literature in this area by analysing the relationship between corporate governance and firms' technical efficiency by extending prior research in several dimensions. Firstly, it aims to analyze whether there exists a positive relation between the quality of corporate governance and the efficiency of SOEs. Secondly, it considers the link between corporate governance-efficiency and the degree of the state ownership of an enterprise. In other terms, whether wholly and majority SOEs experience the same corporate governance-efficiency. Thirdly, we investigate these issues by analyzing empirical data collected from Lithuania, thereby, increasing our knowledge of transitional economics.

\section{Lithuanian Setting}

The Lithuanian setting provides a unique opportunity to analyse the impact of corporate governance mechanisms on SOEs' performance. Firstly, the State of Lithuania controls the largest share of commercial assets in the country and the size of SOE sector relative to the national economy (as measured by employment share) is higher than the OECD average. Secondly, there is a substantial range of business SOEs. As of December 31st 2013, there were 137 state-owned enterprises in Lithuania, ranging from energy (the largest and the most strategically important SOE sector by sales, which includes 9 SOEs), communications (the second largest SOE sector, which includes 23 enterprises), and the forestry sector (which consists of 42 local enterprises). The remaining 57 enterprises were involved in activities varying from minting coins to project evaluation and insurance services [36]. Thirdly, Lithuania is an example of a post-Soviet country, which enables it to demonstrate the applicability of corporate governance standards in SOE management, as an alternative to SOE privatization. The Lithuanian Government initiated the SOE reform with the goal of improving the efficiency and transparency of SOEs and to improve interaction amongst SOEs, the State and the public. The four areas of intervention enforced by the SOE management reforms were: 1) the setting of 
clear objectives; 2) the separation of commercial and non-commercial functions; 3 ) the separation of ownership and regulatory functions; and 4) the increase in the transparency of SOEs (Table 1. For further details, see [37]).

The two cornerstones of SOE reforms were the Government Resolution No. 1052 "On the Approval of the guidelines for ensuring transparency of the activities of the state-owned enterprises and designating a coordinating Authority" ("Transparency Guidelines"), approved on July 2010, and the Government Resolution No. 665 "On the Approval of the guidelines for the Procedure for the Implementation of the State's Property and Non-Property Rights at State-owned Enterprises" ("Ownership Guidelines"), approved on June 2012. The Transparency Guidelines apply to all SOEs, irrespective of size and legal form, whether they are statutory SOEs or limited liability companies. It required SOEs to implement minimum information disclosure standards as outlined in the Corporate Governance Code for listed companies, and to keep accounts in accordance with international accounting standards (IFRS), and to publish annual and quarterly sets of financial statements. The Ownership Guidelines consolidate three main aspects of the SOE management. Provisions on the separation of the state's role as owner and regulator is aimed to separate the state's ownership rights from their sectorial policy function. In this regard, the Governance Coordination Center (GCC) was established as an authority designed to monitor and analyze the implementation of the ownership guidelines by state ownership entities. The provisions relating to boards were aimed at establishing qualification requirements for the board members along with guidelines regarding the composition of the board. The principle of clear objectives was designed to set ambitious objectives for the companies and ensure that all SOEs create comprehensive strategic plans. The state, as their main shareholder, will set the required rate of return for the enterprises. Thus, the two directives effectively prescribe a common set of corporate governance rules for all SOEs.

Table 1. Lithuanian SOEs-areas of intervention of corporate governance reform and relative provisions.

\begin{tabular}{|c|c|}
\hline Areas of intervention & Provisions \\
\hline Set clear objectives & $\begin{array}{l}\text { SOEs are classified into groups according to the level of } \\
\text { commercialization. Performance target (ROE-based) are defined } \\
\text { for each group. Largest SOEs are obliged (others encouraged) to } \\
\text { develop long-term strategies with clear, ambitious objectives. }\end{array}$ \\
\hline $\begin{array}{l}\text { Separation of commercial and } \\
\text { non-commercial functions }\end{array}$ & $\begin{array}{l}\text { Identification, separation and disclosure of SOEs' public policy } \\
\text { objectives ("special obligations"). Compensation mechanism to } \\
\text { cover costs supported for the special obligation. }\end{array}$ \\
\hline $\begin{array}{l}\text { Separation of the ownership and } \\
\text { regulatory function }\end{array}$ & $\begin{array}{l}\text { Establishment of a separate coordinating authority, the Governance } \\
\text { Coordination Center (GCC). Criteria for nomination and compo- } \\
\text { sition of corporate boards. }\end{array}$ \\
\hline Increase the transparency & $\begin{array}{c}\text { Aggregated reporting and disclosure established by law. } \\
\text { SOEs obliged to prepare and publish yearly and } \\
\text { quarterly aggregated reports. }\end{array}$ \\
\hline
\end{tabular}


Overall, Lithuania is an especially suitable case study laboratory for studying the effect of firm-level variation in corporate governance as all Lithuanian SOEs participated in a radical change promoted by through corporate governance reform during the year 2011 and 2012.

\section{Research Design and Data}

The empirical methodology used to investigate the relation between corporate governance and SOEs' performance is presented in this section, along with the description of corporate governance indicators and the data employed for the implementation of the empirical analysis.

\subsection{Empirical Methodology}

The main goal of the paper is to analyse the relationship between corporate governance and SOEs' technical efficiency, rather than market-based or accounting-based performance measures ${ }^{4}$. As pointed out above, this type of productive efficiency is able to examine the basis of corporate governance problems, specifically, inefficient use of resources, not usually easily observable by outside stakeholders and governments.

The empirical methodology is composed of two steps: 1) First step: to measure the efficiency level of the SOE, a Data Envelopment Analysis (DEA) is used. DEA is a popular nonparametric approach well appreciated for its advantages of not imposing prior functional form on the production frontier (less sensitive to misspecification) and the distribution of the inefficiency term and the simultaneous use of multiple inputs and outputs. 2) Second step: to analyse the relationship between corporate governance and SOE performance, we performed a two-stage efficiency analysis based on an ad-hoc bootstrap procedure proposed by [38], that addresses important statistical issues ignored by standard regression (i.e., OLS and Tobit) ${ }^{5}$. In the first step, the efficiency scores were estimated based on a set of inputs and outputs using DEA. In the second step, the efficiency scores were regressed on a set of explanatory variables to ascertain the impact of corporate governance.

At the first step, the DEA was used in order to obtain the SOE's efficiency scores. To briefly outline the DEA estimator, let it be a vector of $H$ inputs that each SOE $k$ $(k=1,2, \cdots, n)$ uses to produce a vector of M outputs, denoted. Then the DEA estimate of the technology set (assuming constant returns to scale and free disposability of inputs and outputs) can be written:

$$
\begin{aligned}
\hat{\Psi}_{D E A}= & \left\{(x, y) \in \mathfrak{R}_{+}^{H} \times \Re_{+}^{M} \mid \sum_{k=1}^{n} z_{k} y_{k}^{m} \geq y^{m}, m=1, \cdots, M\right. \\
& \left.\sum_{k=1}^{n} z_{k} x_{k}^{h} \leq x^{h}, h=1, \cdots, H, z_{k} \geq 0, k=1, \cdots, n\right\}
\end{aligned}
$$

\footnotetext{
${ }^{4}$ Market-based measures are excluded, as the majority of Lithuanian SEOs are not listed. Accounting-based measures are inappropriate to compare firms, which use multiple inputs and produce multiple outputs. ${ }^{5}$ Serious problems in the two-stage approach arise from the fact that DEA efficiency estimates are serially correlated. Consequently, standard approaches to inference are invalid.
} 
where $\left\{z_{k} \geq 0: k=1, \cdots, n\right\}$ are the intensity variables over which the maximization will be made. Under certain regular conditions on the data generating process (DGP), the expression in (1) provides a consistent estimator of the unknown technology ${ }^{6}$. Once the technology is estimated, we derive the efficiency scores by measuring for each SOE the radial distance to the frontier, according to the [2]-[4] [7] [8] [24] [41] [42] criterion. In particular, we use the output-oriented measure of technical efficiency defined as:

$$
T E(x, y)=\max _{\theta, z_{1}, \cdots, z_{n}}\left\{\theta \mid(x, \theta y) \in \hat{\Psi}_{D E A}\right\}
$$

This is a consistent estimator of the true efficiency score from a point to the frontier of the true technology set in (1).

At the second step, we estimated a multivariate relationship between corporate governance and efficiency, controlling for other SOE characteristics including the legal status. To do so, we followed the truncated regression with the bootstrap approach, suggested by [38], to analyze the following relationship:

$$
T E_{k}=Z_{k} \beta+u_{k}, \quad k=1, \cdots, n
$$

where $T E_{k}$ is the true (in) efficiency score of $\operatorname{SOE} k$, while $Z_{k}$ is the (row) vector of repressors (corporate governance indices and specific SOEs characteristics) that are believed to influence the (in) efficiency score of SOE $\mathrm{k}$ through the (column) vector of parameters $\beta$, which we aim to estimate, while $u_{k}$ is a random error. Obviously, the true inefficiency score, $T E_{k}$, is unobserved and so we replaced it with its DEA estimate from the first stage, corrected for the bias via the bootstrap procedure that accounts for the production model in (1) and the hypothesized structure in (3). Importantly, because, we also have $T E_{k} \geq 1$ for all $u_{k} \geq 1-Z_{k} \beta$, and, to account for this boundary issue, we used the truncated regression approach, by assuming $u_{k} \sim N\left(0, \sigma_{\varepsilon}^{2}\right)$ such that $u_{k} \geq 1-Z_{k} \beta, \quad k=1, \cdots, n$, where $\sigma_{\varepsilon}^{2}$ is estimated along with $\beta$. To improve the accuracy of the inference, we used the parametric bootstrap (reflecting the structure in (3)) to obtain confidence intervals around each element in $\beta$. This procedure is described in more detail in Simar and Wilson (2007).

\subsection{Sample Selection, Data and Corporate Governance Measures}

The first step of our empirical methodology was to measure the SOE's efficiency scores. To address this issue we defined the SOEs' production model with one output and three inputs, following [11]. On the output side, we selected total revenues. On the input side, we selected 1) labor, measured by total labor expenses, 2) capital stock, measured by tangible assets, and 3) other costs, measured by total production costs minus depreciation. This means that what we can practically model is not the original [42] technical efficiency, but efficiency that includes the technical and some types of allocative [in] efficiencies. Accordingly, the efficiency measure reflects the SOE's ability to generate financial returns from the minimum feasible consumption of capital (i.e., fixed assets), 
the labor and operational costs incurred. Such input and output measurements justify the pooling of data across industries to measure the efficiency of each SOE under one DEA-measured "best-practice frontier" at the first stage. The technology set, as defined in Equation (1), characterizes a set of possibilities to generate revenues out of investments into major inputs, regardless of specific engineering, managerial and other business features.

Our primary source of data was the dataset provided by the Lithuanian Governance Coordination Center (GCC). The dataset contained information from annual financial statements of all commercial Lithuanian SOEs and covered the years 2012 and 2013. The initial sample consisted of all commercial SOEs. Of these 101 first selected, five were excluded because of missing information from the annual reports. One additional SOE was excluded because it outsourced its labor force ${ }^{7}$. The final sample, consisted of 190 firm-year observations from wholly and majority SOEs.

The second step of the empirical methodology required the definition of corporate governance measures. In Lithuania, the GCC is the first and sole provider of corporate governance measures of SOEs. By law, it periodically assesses the implementation of good governance practices among Lithuanian SOEs with the aim of monitoring how successfully enterprises follow OECD recommendations and provisions of Ownership Guidelines and Transparency Guidelines [36]. Indexes (or ratings) are calculated based on questionnaires responded to either by SOEs themselves or institutions exercising the right of the owner of the SOE.

GCC reports global measures on three corporate governance mechanisms: quality of transparency, quality of boards and quality of strategic planning, strategic implementation and controls. Each index is computed as an aggregation of indices measuring corporate governance subcategories. For instance, Quality of transparency has been derived as a combination of four indices concerning: 1) Comprehensiveness of SOE summary reports; 2) SOE social responsibility; 3) Application of international accounting standards, and () Opinion of external auditors. Quality of boards has been derived as combination of six indices concerning: 1) Board independency; 2) Board competences; 3) Presence of SOE employees on the boards; 4) Board members' participation; 5) Board committees; and 6) Selection of board members. Quality of strategic planning, strategic implementation and control have been derived as combinations of three indices concerning: 1) Quality of corporate strategies; 2) Supervision of strategy implementation and internal control system; and 3) Implementation of corporate objectives (see Appendix for further details on the assessment criteria).

Each single index has been evaluated on the scale from 1, meaning poor implementation of the appropriate guidance, to 3 meaning full compliance, and then aggregated and standardized over a scale 0 - 10 (higher numbers indicate better governance) to form a corporate governance global measure.

To mitigate potential measurement error in the individual scores and provide a complete picture of the state of governance, we defined two aggregate measures of corpo-

\footnotetext{
${ }^{7}$ In fact, one would expect that outsourcing labor force enhance efficiency given the lower input usage.
} 
rate governance indexes that take simultaneously into account the three corporate governance mechanisms (i.e. quality of transparency, quality of board, and quality of strategic planning, strategic implementation and control). These indicators provide a more general picture of the overall corporate governance quality, instead of focusing on specific aspects, which could provide only a partial view. More specifically, we obtained the Factor Corporate Governance Index as the weighted sum of the original variables with weights represented by the value of the first eigenvalue of the corporate governance indexes. The second aggregate measure was obtained by averaging the individual corporate governance indexes into an aggregate index, the Average Corporate Governance Index.

Overall, the Lithuanian setting is unique insofar as it provides for the first time corporate governance measures for a post-Soviet country. Our study exploits this database by explicitly linking the efficiency to these corporate governance measures. The definition of two aggregate indexes allows the performance of an empirical exercise using multiple corporate governance indices, which have significant differences in emphasis. This fact offers us the opportunity to investigate whether corporate governance indices aggregated into a composite index, which provides a more complete picture of the state of governance, have an impact on efficiency.

The descriptive statistics of inputs and outputs included on the production model, and the corporate governance measures are shown in Table 2 and Table 3, respectively. Table 2 provides information about the inputs used and outputs produced by wholly and majority SOEs and the entire sample. Data in nominal values are converted to real

Table 2. Descriptive statistics of firm inputs and outputs.

\begin{tabular}{ccccccc}
\hline & \multicolumn{3}{c}{2012 Mean (Median) } & \multicolumn{2}{c}{ 2013 Mean (Median) } \\
\cline { 2 - 7 } Variable & $\begin{array}{c}\text { Whole } \\
\text { Sample }\end{array}$ & $\begin{array}{c}\text { Wholly } \\
\text { State-Owned } \\
\text { Enterprise }\end{array}$ & $\begin{array}{c}\text { Majority } \\
\text { State-Owned } \\
\text { Enterprise }\end{array}$ & $\begin{array}{c}\text { Whole } \\
\text { Sample }\end{array}$ & $\begin{array}{c}\text { Wholly } \\
\text { State-Owned } \\
\text { Enterprise }\end{array}$ & $\begin{array}{c}\text { Majority } \\
\text { State-Owned } \\
\text { Enterprise }\end{array}$ \\
\hline Size & & & & & & \\
Total Assets & 67,232 & 16,695 & 139,799 & 67,865 & 17,232 & 140,570 \\
Inputs & $(3799)$ & $(3909)$ & $(2765)$ & $(3882)$ & $(4035)$ & $(2801)$ \\
Labor & 4179 & 1430 & 8127 & 4308 & 1456 & 8403 \\
Capital & $(916)$ & $(1033)$ & $(615)$ & $(973)$ & $(1061)$ & $(676)$ \\
& 58,003 & 13,460 & 121,961 & 58,985 & 14,712 & 122,557 \\
Costs & $(2010)$ & $(2212)$ & $(1465)$ & $(2054)$ & $(2371)$ & $(1677)$ \\
& 18,239 & 2961 & 40,177 & 17,414 & 3040 & 38,053 \\
Outputs & $(1854)$ & $(1959)$ & $(954)$ & $(1982)$ & $(2125)$ & $(1184)$ \\
Revenues & 23,440 & 5,040 & 49,861 & 22,989 & 5146 & 48,610 \\
& & & & & $(3413)$ & $(1838)$ \\
N. obs & $(3060)$ & $(3253)$ & $(1905)$ & $(3140)$ & 56 & 39 \\
\hline
\end{tabular}


Table 3. Descriptive statistics of the corporate governance indexes.

\begin{tabular}{cccccccccccc}
\hline & \multicolumn{3}{c}{ Wholly State-Owned Enterprise } & \multicolumn{3}{c}{ Majority State-Owned Enterprise } \\
\cline { 2 - 10 } & mean & median & $\min$ & $\max$ & std & mean & median & min & max & std \\
\hline $\begin{array}{c}\text { Factor Corporate } \\
\text { Governance Index }\end{array}$ & 5.63 & 6.24 & 0.9 & 7.16 & 1.41 & 4.54 & 4.25 & 0 & 10 & 2.17 \\
$\begin{array}{c}\text { Average Corporate } \\
\text { Governance Index }\end{array}$ & 5.71 & 6.04 & 2.48 & 6.57 & 0.88 & 5.28 & 5.04 & 2.69 & 9.26 & 1.51 \\
$\begin{array}{c}\text { Transparency Index } \\
\text { Board Index }\end{array}$ & 6.35 & 6.8 & 2.98 & 7.67 & 1.02 & 5.86 & 6.06 & 3.33 & 8.89 & 1.48 \\
$\begin{array}{c}\text { Strategic Planning and } \\
\text { Internal Control Index }\end{array}$ & 7.82 & 8.75 & 3.13 & 10 & 1.64 & 5.95 & 5.94 & 0 & 10 & 2.45 \\
\hline
\end{tabular}

terms using the GDP deflator (euro) with base year 2013. Descriptive statistics suggest that, in terms of sample composition, the number of observations from wholly SOEs exceeds the number of observations from majority SOEs. Moreover, majority SOEs use, on average, more input resources and produce a larger amount of revenues. However, when we compare the median values, this pattern changes in favor of wholly SOEs. In terms of size, the majority of SOEs are larger than wholly owned SOEs.

Overall, Table 2 shows that wholly and majority SOEs differ in the input usage and output production, and may be portraying different behavior in approaching the "best-practices frontier". Table 3 presents descriptive statistics for the three corporate governance measures along with the two aggregate corporate governance indexes, broken down into wholly and majority SOEs. The table shows that wholly SOEs experience higher quality of corporate governance than majority SOEs. When we look at each corporate governance index, it seems that wholly SOEs have better governance in transparency and strategic planning and internal control. The opposite is true with regard to board quality.

The information given by the descriptive statistics guides us to formulate two research questions: 1) whether (or not) there exists efficiency inequality between wholly and majority SOEs and if so, which form of ownership, wholly vs. majority, leads to higher efficiency; and 2) given the differences in terms of corporate governance quality between wholly and majority SOEs, it seems reasonable to investigate whether heterogeneous behavior might play a role in Lithuanian SOE's performance..

This table shows the state-owned enterprises (SOEs) sample characteristics in terms of size, inputs and outputs defining the selected production frontier. The sample is constructed by selecting commercial SOEs excluding five SOEs with missing financial data and one SOE that uses labor outsourcing. The table details data for the whole sample, wholly SOEs, and majority SOEs during the year 2012, 2013. Financial variables are expressed in thousand Euros and are converted to real terms using the GDP deflator with base year 2013 .

\section{Results}

Following our research methodology and the research questions that emerged from the 
descriptive analysis, we first present the estimates from the efficiency analysis relating to the performance of SOEs, considered as a whole and across the two groups, wholly vs. majority SOEs. Estimates from testing whether there existed significant efficiency inequality between wholly and majority SOEs were also reported. The second step was to examine, the relationship between corporate governance and the SOEs' efficiency. This was analyzed in a multivariate setting by using the second-stage truncated regression with bootstrap.

\subsection{Univariate Efficiency Analysis}

Results from the first stage of our research methodology provide insights into whether wholly and major SOEs were equally efficient. Table 4 provides efficiency estimates (biased and bias-corrected respectively) across the two groups of SOEs and the entire sample. As the aim of the analysis was to explain the inefficiency, efficiency scores are reported à la Farrell (1957): the closer the score to unity, the more efficient the SOE. However, to easily interpret the results, we report the efficiency score à la Shephard [43], which are the reciprocal of the Farrell efficiency scores and represent the relative \%-level of efficiency, in the discussion.

We report the average of the (bias-corrected) efficiency of the whole sample and by group (wholly state-owned enterprises vs. majority state-owned enterprises). The first and the second columns report, respectively, the biased efficiency (Eff.) and the biascorrected efficiency (BC-Eff.). The third and fourth columns report the bias term (Est. Bias) and the estimated standard deviation (Est-Std.).

Since the results presented in Table 4 show that the estimated bias is negative, suggesting that our original efficiency is overestimated, and the standard deviation indicates that the estimated bias is statistically different from zero in nearly all cases, we discuss the results in terms of the bias corrected efficiency (BC-Eff). A key result is that SOEs exhibit inefficiency greater than $10 \%$ since they register an average efficiency value of $81.25 \%$ (Farrell measure is equal to 1.231 ) and a median efficiency equal to 88.78\% (Farrell measures is equal to 1.126). This result indicates that, despite the implementation of the corporate governance measures, Lithuanian SOEs have not fully eliminated all inefficiencies.

Considering the breakdown in wholly and majority SOEs, we find that wholly SOEs have an efficiency score of $83.95 \%$ (Farrell measure is equal to 1.192) which seems higher with respect to the efficiency of majority SOEs that is equal to $77.72 \%$ (Farrell

Table 4. Efficiency estimations.

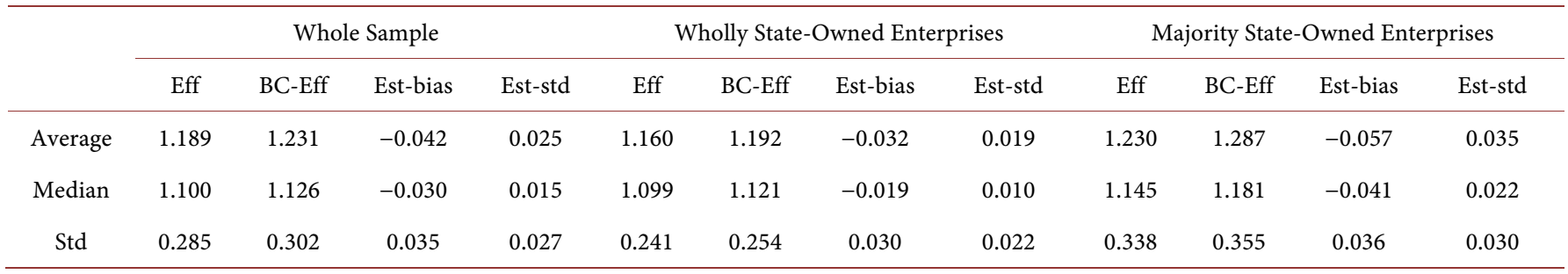


measure is equal to 1.287). Thus, it seems that there exists inequality between the efficiency of the two groups of SOEs, wholly vs. majority. To confirm this assertion, we test if the difference of the average efficiency scores of the two groups is statistically significant by applying the bootstrap-based procedure. We use the bootstrap to estimate the p-value of a null hypothesis $\mathrm{H}_{0}$, i.e. wholly SOEs and majority SOEs have the same average efficiency score. With 2000 bootstrap replications, we obtain a p-value of 0.9895 . As a result, the null hypothesis of equality of mean efficiency between wholly and majority SOEs cannot be rejected. Overall, we find that average wholly SOEs perform better that average majority SOEs, nevertheless, this difference is not statistically meaningful. Thus, the results show that there does not exist efficiency inequality between wholly and majority SOE as was suspected from the descriptive statistic analysis.

Having obtained the efficiency scores of Lithuanian SOEs and compared the performance of the two SOEs' groups, the second step of our methodology was aimed at investigating the role of corporate governance on the SOEs efficiency. We were able to investigate whether there existed a difference between the efficiency of both groups of SOEs, once we accounted for corporate governance and other tangible specific variables.

This table shows the statistics (average, median and standard deviation) of the original efficiency estimates (Eff.), the corresponding estimated bias (Est-bias), and the estimated standard deviation across bootstrap replication (Est-std). The second column show the bias-corrected efficiency estimates (BC-Eff.). Results are reported for the whole sample as well as for the two groups of SOEs, Wholly State-Owned Enterprises and Majority State-Owned Enterprises.

\subsection{Multivariate Test of the Corporate Governance Hypothesis}

To examine the role of corporate governance mechanisms in improving the efficiency of Lithuanian SOEs, we estimated a battery of regressions based on the econometric model described in Equation (3), adopting the SOE bias-corrected inefficiency score as the dependent variable and corporate governance indexes, both at aggregate and disaggregated level, as independent variables. Additional to the corporate governance indexes, the regressions contain a set of individual SOE characteristics. Specifically, we introduced a binary indicator variable into our models to analyse whether the relationship between efficiency and corporate governance did in fact differ across wholly and majority SOEs, once we controlled for other variables, i.e. to test whether there existed an inequality in efficiency between the groups of SOEs. Furthermore, to investigate whether heterogeneous behavior in the quality of corporate governance plays, to some degree, a role in the Lithuanian SOEs performance, given differences in terms of corporate governance quality between wholly and majority SOEs, the cross product between corporate governance and the binary indicator variable for wholly SOE was introduced. Lastly, we introduced controls for size (measured as the logarithm of total assets) and financial leverage, measured as the ratio of equity to total assets. These variables are intended to control for heterogeneity in firms' business processes. Lastly, 
we introduce a binary indicator to control for the effects of listing status.

The parameters of second-stage regression described above (Equation (3)) are estimated according to [38] algorithm 2 with 1000 bootstrap replications to obtain the bias correction and 1000 bootstrap replications to obtain the parameters' confidence intervals. For each parameter, we estimated the relative 99\%, 95\%, and 90\% confidence intervals. The effect of the independent variable would not be significant at the $0.01,0.05$, and 0.10 level if the relative confidence interval contained zero (that is the parameter value specified in the null hypothesis). Recall that the parameters with a negative sign indicate sources of efficiency, as DEA bias-corrected estimates are measures of inefficiency (i.e., measured à la Farrell).

Table 5 shows the results obtained from the Model 1 and 2. Both models contain the corporate governance indexes as independent variables. However, while in Model 1 the aggregate corporate governance index is constructed as a linear combination of the corporate governance indexes (Factor Corporate Governance Index), using the first eigenvector of the greater eigenvalue of the corporate governance indexes matrix as the weight coefficient, in Model 2 the aggregate corporate governance index was constructed as the average of the corporate governance indexes (Average Corporate Governance Index). The results contained in Table 5 show that the coefficient of the Factor Corporate Governance Index in Model 1 and the coefficient of the Average Corporate Governance Index in Model 2 are both statistically negative, meaning that better quality of corporate governance reduces inefficiency. This finding is consistent with our hypothesis that higher quality of corporate governance in SOEs enables an increase of relative efficiency.

Turning to the ownership hypothesis, i.e. whether inequality in efficiency exists between the two groups of SOEs, the coefficient on Wholly SOEs has a negative sign and is significant in both models (Model 1 and Model 2), indicating that wholly SOEs are more efficient than majority SOEs. This implies that there is a positive link between participation of full state capital in SOE ownership and higher technical efficiency. This result is in line with [16] who find a U-shaped relationship between corporate value

Table 5. Truncated regression results with Aggregate Corporate Governance Index as the independent variable.

\begin{tabular}{ccc}
\hline Variables & Model 1 & Model 2 \\
\hline Intercept & 1.235 & $3.230^{\star *}$ \\
Corporate Governance Index & $-0.469^{\star *}$ & $-0.763^{\star *}$ \\
Wholly SOE & $-3.071^{\star *}$ & $-5.586^{\star *}$ \\
Corporate Governance Index x Wholly SOE & $0.563^{\star *}$ & $0.970^{\star *}$ \\
Size & $0.338^{\star *}$ & $0.339^{\star *}$ \\
Listed SOE & -0.494 & -0.199 \\
Leverage & $-3.701^{\star *}$ & $-3.831^{\star *}$ \\
$\sigma_{u}^{2}$ & $0.435^{\star *}$ & $0.428^{\star}$ \\
\hline
\end{tabular}

${ }^{*}$ Significant at $10 \% ;{ }^{* *}$ significant at $5 \% ;{ }^{* * *}$ significant at $1 \%$. 
and government ownership for Chinese firms: as ownership concentration approaches $100 \%$, the relation between ownership concentration and firm efficiency is positive. Moreover, it confirms the existence of a possible conflict of interests between the State (as the largest shareholder) and private entities (as minority shareholders) that reduces firm efficiency. Turning to the hypothesis on the interaction between ownership structure and effectiveness of corporate governance mechanisms, the interaction between wholly SOE and the aggregate corporate governance measure (Model 1 and Model 2), exhibits a positive and statistically significant sign, suggesting that wholly SOEs mitigate the positive effects of corporate governance mechanisms on efficiency compared to the benefits obtained by majority SOEs.

Overall, the results suggest that corporate governance mechanisms are more effective for majority SOEs than for wholly SOEs. However, the ownership structure of Wholly SOEs per se improves efficiency.

This table reports estimates from the truncated regressions of the inefficiency on aggregate corporate governance index and control variables. In Model 1, the aggregate corporate governance index is constructed as a linear combination of the corporate governance indexes, using the first eigenvector of the greater eigenvalue of the corporate governance indexes' matrix as the weight coefficient (Factor Corporate Governance Index). In Model 2, the aggregate corporate governance index is constructed as the average of the corporate governance indexes (Average Corporate Governance Index). We include the following independent variables: Size measured as log (total assets), Leverage and two dummies (Wholly SOE and Listed SOE). ${ }^{*}$ Significant at $10 \%$; ${ }^{* *}$ significant at $5 \% ;{ }^{* *}$ significant at $1 \%$.

An interesting observation from the results obtained in Table 5 is the fact that the positive effect of the corporate governance mechanism on efficiency for wholly SOEs is diminished to a lower extent when the Factor Corporate Governance Index is used. This result seems to suggest that there may be some categories of corporate governance that are dominating the effect on efficiency.

In our next tests, hence, we analyze the impact of each of the components of the corporate governance indexes over the efficiency of the SOEs (Model 3 through Model 5). Table 6 shows that results in Model 3, 4 and 5 for each of the corporate governance measures, confirming the results in Table 5. Board Index and Strategic Planning Index show a significantly negative coefficient. In Model 6, we estimate the combined model that simultaneously includes Transparency Index, Board Index, and Strategic Planning Index ${ }^{8}$. We found consistent results with Model 3, 4, 5. Specifically, Board Index and Strategic Planning Index are negative and statistically significant, indicating their positive contribution to enhance the SOEs' efficiency. Although the Transparency Index has expected sign in all models, it is statistically insignificant from zero, suggesting a neutral impact on efficiency. This result is in line with [26] who, though using a different proxy for transparency, found this corporate governance quality indicator did not affect

${ }^{8}$ This model is more representative as it measures efficiency changes associated with a change in one of the corporate governance index when all other predictor variables are held constant. 
Table 6. Truncated regression results with Corporate Governance Index as the independent variable.

\begin{tabular}{ccccc}
\hline Variables & Model 3 & Model 4 & Model 5 & Model 6 \\
\hline Intercept & $2.366^{*}$ & $2.040^{*}$ & 0.651 & $3.083^{* * *}$ \\
Transparency Index & -0.292 & & & -0.141 \\
Board Index & & $-0.321^{* *}$ & & $-0.306^{* *}$ \\
Strategic Planning Index & & & $-0.473^{* * *}$ & $-0.325^{* * *}$ \\
Wholly SOE & -2.552 & $-3.605^{* *}$ & $-3.662^{* * *}$ & $-5.302^{* * *}$ \\
Transparency Index x & 0.338 & & & 0.125 \\
Wholly SOE & & & & $0.849^{* *}$ \\
Board Index x Wholly SOE & & $0.938^{* * *}$ & & 0.248 \\
Strategic Planning Index x & & & $0.500^{* * *}$ & \\
Wholly SOE & & & & $0.391^{* * *}$ \\
Size & -0.146 & $-0.225^{*}$ & -1.496 & -0.260 \\
Listed SOE & $-3.425^{* *}$ & $-5.069^{* * *}$ & $-4.324^{* * *}$ & $-4.578^{* *}$ \\
Leverage & $0.453^{*}$ & $0.524^{* *}$ & $0.545^{* * *}$ & $0.479^{* *}$ \\
$\sigma_{u}^{2}$ & & & & \\
\hline
\end{tabular}

${ }^{*}$ Significant at $10 \%$; ${ }^{*}$ significant at $5 \%$; ${ }^{* *}$ significant at $1 \%$.

the efficiency. Turning to the ownership hypothesis, Model 4 through Model 6 confirms previous results, namely Wholly SOEs have a negative and statistically significant sign, indicating that wholly SOEs are more efficient that majority SOEs.

The interaction between wholly SOEs and corporate governance indexes is interesting and needs to be extensively analyzed in order to test which of the three main components is contributing more to mitigate the positive effect of corporate governance on efficiency in the case of wholly SOEs. Although both Board Index and the Strategic Planning Index show a statistically positive coefficient, the transparency mechanism seems to have no impact on wholly SOE efficiency, however, the Board Index is the component which contributes the most to lowering the positive impact of corporate governance on wholly SOE efficiency. The contribution of Board Index (Strategic Planning Index) to the decrease of efficiency for Wholly SOEs is 0.938 (0.5) in Model 4 (Model 5). The results of the interaction between wholly SOEs and each other corporate governance component, when the three corporate governance indexes are simultaneously included in the combined model (Model 6). The only component that affects negatively the efficiency of Wholly SOEs is the Board Index (0.849). Thus, it seems that the quality that the Board corporate governance component is a key variable influencing positively the efficiency of the SOEs in Lithuania. Recalling the descriptive statistics in Table 3, we found that wholly SOEs have better governance in transparency and strategic planning and internal control than majority SOEs, however, the opposite is true with regard to the board. Thus, it seems that the worse board governance (that is lower board quality given, for instance, by a lack of board independence or lack of spe- 
cific competences among board members) in wholly SOEs, is the main reason that causes their deterioration on efficiency in terms of corporate governance. In other terms, in wholly SOEs the quality of board has a limited role in mitigating the agency problems, while ownership concentration plays a dominant role. This might lead to the assumption that the lower impact of the board quality in wholly SOEs compared to majority SOEs may possibly stem from potential governance decisions being highly politicized in the wholly SOEs, as pointed out by the OECD Guidelines (2005). Lastly, this confirms the existence of interactions between ownership structure and board quality.

As far as the controlling variables are concerned, in all specification models (Model 1 through Model 6) the estimated coefficient of the scale effect has been found to be positively associated with inefficiency for all specifications: the larger the SOEs the higher the losses in efficiency. Secondly, the listed status is not always statistically significant, although with the right sign. Third, financial leverage is positively associated to efficiency, in all specifications.

This table reports estimates from truncated regressions of the inefficiency on specific corporate governance index and control variables. In Model 3, the corporate governance index is the Transparency Index, In Model 4 the Board Index, and in Model 5 the Strategic Planning Index. Model 6 includes the three indexes simultaneously. We include the following independent variables: Size measured as log (total assets), Leverage and two dummies (Wholly SOE and Listed SOE). ${ }^{\star}$ Significant at $10 \%$; ${ }^{\star *}$ significant at $5 \% ;{ }^{* * *}$ significant at $1 \%$.

\section{Conclusions}

In this paper, we analyzed whether, and to what extent, corporate governance mechanisms affect the efficiency of SOEs operating in transition economies and whether the link between corporate governance-efficiency varies with the degree of state ownership (wholly SOEs vs. majority SOEs). Such analysis is potentially relevant for independent research interests along with policy formation and implementation giving the importance that good corporate governance has for the progress and prosperity of any enterprise, and its essential importance for the efficiency and growth of the domestic and international economies. This issue achieves more importance when it is analyzed within the context of transition countries, as in this study, which analyzes the case of Lithuania, where SOEs play an important role, controlling the largest share of commercial assets in the country. In particular, we exploited a unique dataset of corporate governance ratings of commercial Lithuanian SOEs over the period after the introduction of reforms in the years of 2012 and 2013. We focused first on a composite index of corporate governance ratings as one dimension of corporate governance quality and subsequently we focus on each single corporate governance index. We set up a two-stage empirical research strategy that combined a non-parametric efficiency estimator (i.e., DEA) with bootstrapped truncated regression. At the first step, we estimated technical efficiency for SOEs in Lithuania and explored potential efficiency differences between 
the two SOE's ownership structures: wholly vs. majority SOEs. Then, we estimated a battery of regressions, which linked individual SOEs' technical efficiency scores to the corporate governance aggregate and individual ratings, respectively.

In contrast with previous empirical works, this paper strives to capture the interplay between the two types of ownership structure of SOEs and the quality of corporate governance practices implemented in the recent reforms of SOEs in Lithuania.

The results reveal that wholly state controlled SOEs are associated with greater efficiency when compared with a mixed form of State and minority interest ownership. However, this superiority in efficiency is explained in terms of ownership structure and not in terms of corporate governance. This is confirmed firstly by our regression results where the composite corporate indexes are used, as wholly state governed SOEs seem to benefit less from the overall corporate governance practices. Results from regressions where each corporate governance index is used, highlight that board quality and strategic planning show less efficiency when compared with majority SOEs. Although, the key result obtained in the paper is that it seems that the most important effect on improving efficiency of the SOEs comes from quality of the board and strategic planning, taken together they have a larger impact only in the case of majority SOEs.

Overall, our findings confirm that restructuring SOEs via corporate governance reform plays a crucial role in enhancing efficiencies; however, wholly SOEs are not able to exploit the beneficial effects of corporate governance practices due to their lower levels of board quality and strategic planning, the key driver being low board quality. Several policy implications might be identified for continuing corporate governance reform in Lithuanian. First, there is further room for improving the quality of corporate governance practices among wholly run SOEs, and in particular the state should strive to continue to reduce aggressively, undue political interference or passive state ownership. Because of the efficiency losses incurred by wholly state run SOEs due to weak corporate governance, the state needs to develop unique competencies and should employ professionals with legal, financial, economic and management skills. Second, given the inefficiencies found in the majority SOEs, efforts should be made to mitigate potential conflicts of interests between state and private ownership. Further research is needed to investigate efficiency differences between SOEs and non-SOEs in transition countries as well as difference of the impact of corporate governance practices.

\section{Acknowledgements}

We thank participants at the 6th International Conference of the Financial Engineering and Banking Society, 2016 for helpful comments and suggestions. We are also grateful to The Property Bank, State-Owned Enterprise Governance Coordination Unit in Lithuania and especially Marius Barys and Dainius Velykis for providing us additional data on Lithuanian SOEs and being always available for questions and consultations. Claudia Curi and Ana Lozano-Vivas gratefully acknowledge financial support from the Free University of Bolzano-Bozen and the Ministerio de Economía y Competitividad (through the research grant ECO2014-52345-P). 


\section{References}

[1] Claessens, S. and Yurtoglu, B.B. (2013) Corporate Governance in Emerging Markets: A Survey. Emerging Market Review, 15, 1-33. http://dx.doi.org/10.1016/j.ememar.2012.03.002

[2] Dnes, A.W. (2005) Corporate Governance: An International Perspective. Managerial and Decision Economies, 26, 411-412. http://dx.doi.org/10.1002/mde.1261

[3] Denis, D.K. and McConnell, J.J. (2003) International Corporate Governance. Journal of Financial and Quantitative Analysis, 38, 1-36. http://dx.doi.org/10.2307/4126762

[4] Estrin, S., Hanousek, J., Kocenda, E. and Svejnar, J. (2009) The Effects of Privatization and Ownership in Transition Economies. Journal of Economic Literature, 47, 1-30. http://dx.doi.org/10.1257/jel.47.3.699

[5] Megginson, W. (2005) The Economics of Bank Privatization. Journal of Banking and Finance, 29, 1931-1980. http://dx.doi.org/10.1016/j.jbankfin.2005.03.005

[6] Boycko, M., Shleifer, A. and Vishny, R.W. (1996) A Theory of Privatization. Economic Journal, 106, 309-319. http://dx.doi.org/10.2307/2235248

[7] Dewenter, K. and Malatesta, P. (2001) State-Owned and Privately Owned Firms: An Empirical Analysis of Profitability, Leverage, and Labor Intensity. American Economic Review, 91, 320-334. http://dx.doi.org/10.1257/aer.91.1.320

[8] Djankov, S. and Murrell, P. (2002) Enterprise Restructuring in Transition: A Quantitative Survey. Journal of Economic Literature, 40, 739-792. http://dx.doi.org/10.1257/jel.40.3.739

[9] Megginson, W. and Netter, J.N. (2001) From State to Market: A Survey of Empirical Studies on Privatization. Journal of Economic Literature, 39, 321-389.

http://dx.doi.org/10.1257/jel.39.2.321

[10] Shleifer, A. (1998) State versus Private Ownership. Journal of Economic Perspectives, 12, 133-150. http://dx.doi.org/10.1257/jep.12.4.133

[11] Su, D. and He, X. (2012) Ownership Structure, Corporate Governance and Productive Efficiency in China. Journal of Productivity Analysis, 28, 303-318. http://dx.doi.org/10.1007/s11123-011-0257-8

[12] Allen, F. and Gale, D. (2000) Corporate Governance and Competition. In: Vives, X., Ed., Corporate Governance: Theoretical and Empirical Perspectives, Cambridge University Press, Cambridge, 23-90. http://dx.doi.org/10.1017/CBO9781139175333.003

[13] Dahya, J., Dimitrov, O. and McConnell, J.J. (2008) Dominant Shareholders, Corporate Boards and Corporate Value: A Cross-Country Analysis. Journal of Financial Economics, 87, 73-100. http://dx.doi.org/10.1016/j.jfineco.2006.10.005

[14] Vickers, J. and Yarrow, G. (1991) Economic Perspectives on Privatization. Journal of Economic Perspectives, 5, 111-132. http://dx.doi.org/10.1257/jep.5.2.111

[15] Gupta, N. (2005) Partial Privatization and Firm Performance. The Journal of Finance, 60, 987-1015. http://dx.doi.org/10.1111/j.1540-6261.2005.00753.x

[16] Tian, L.H. and Estrin, S. (2008) Retained Shareholding in Chinese PLCs: Does Government Ownership Always Reduce Corporate Value? Journal of Comparative Economics, 36, 7489. http://dx.doi.org/10.1016/j.jce.2007.10.003

[17] Stiglitz, J.E. (1999) Wither Reform? Ten Years of Transition. Keynote Address at Annual Bank Conference on Development Economics, World Bank, Washington DC, 28-30 April 1999.

[18] Chen, G., Firth, M. and Xu, L. (2009) Does the Type of Ownership Control Matter? Evidence from China's Listed Companies. Journal of Banking and Finance, 33, 171-181. http://dx.doi.org/10.1016/j.jbankfin.2007.12.023 
[19] McConnell, J.J. and Servaes, H. (1990) Additional Evidence on Equity Ownership and Corporate Value. Journal of Financial Economics, 27, 595-612.

http://dx.doi.org/10.1016/0304-405X(90)90069-C

[20] Black, B. (2001) The Corporate Governance Behavior and Market Value of Russian Firms. Emerging Markets Review, 2, 89-108. http://dx.doi.org/10.1016/S1566-0141(01)00012-7

[21] Black, B., Jang, H. and Kim, W. (2006) Does Corporate Governance Affect Firms' Market Values? Evidence from Korea. Journal of Law, Economics, and Organization, 22, 366-413. http://dx.doi.org/10.1093/jleo/ewj018

[22] Black, B., Kim, W., Jang, H. and Park, K.S. (2006b) Does Corporate Governance Predict Firms' Market Values: Time-Series Evidence from Korea. http://ssrn.com/abstract=844744

[23] Black, B., Love, I. and Rachinsky, A. (2006) Corporate Governance Indices and Firms' Market Values: Time Series Evidence from Russia. Emerging Markets Review, 7, 361-379. http://dx.doi.org/10.1016/j.ememar.2006.09.004

[24] Durnev, A. and Kim, E.H. (2005) To Steal or Not to Steal: Firm Attributes, Legal Environment, and Valuation. The Journal of Finance, 60, 1461-1493. http://dx.doi.org/10.1111/j.1540-6261.2005.00767.x

[25] Klapper, L.F. and Love, I. (2004) Corporate Governance, Investor Protection, and Performance in Emerging Markets. Journal of Corporate Finance, 10, 287-322. http://dx.doi.org/10.1016/S0929-1199(03)00046-4

[26] Zelenyuk, V. and Zheka, V. (2006) Corporate Governance and Firm's Efficiency: The Case of a Transitional Country, Ukraine. Journal of Productivity Analysis, 25, 143-157. http://dx.doi.org/10.1007/s11123-006-7136-8

[27] Zheka, V. (2005) Corporate Governance, Ownership Structure and Corporate Efficiency: The Case of Ukraine. Managerial and Decision Economics, 26, 451-460. http://dx.doi.org/10.1002/mde.1258

[28] Bryan, S., Nash, R. and Patel, A. (2010) How the Legal System Affects the Equity Mix in Executive Compensation. Financial Management, 39, 393-418. http://dx.doi.org/10.1111/j.1755-053X.2010.01077.x

[29] Gibson, M.S. (2003) Is Corporate Governance Ineffective in Emerging Markets? The Journal of Financial and Quantitative Analysis, 38, 231-250. http://dx.doi.org/10.2307/4126771

[30] Claessens, S., Djankov, S. and Lang, L. (2000) The Separation of Ownership and Control in East Asian Corporations. Journal of Financial Economics, 58, 81-112. http://dx.doi.org/10.1016/S0304-405X(00)00067-2

[31] Holderness, C.G. (2003) A Survey of Blockholders and Corporate Control. Economic Policy Review, 9, 51-63.

[32] La Porta, R., Lopez-de-Silanes, F., Shleifer, A. and Vishny, R.W. (2000) Investor Protection and Corporate Governance. Journal of Financial Economics, 58, 3-27. http://dx.doi.org/10.1016/S0304-405X(00)00065-9

[33] La Porta, R., Lopez-De-Silanes, F., Shleifer, A. and Vishny, R. (2002) Investor Protection and Corporate Valuation. The Journal of Finance, 57, 1147-1170. http://dx.doi.org/10.1111/1540-6261.00457

[34] Leibenstein, H. (1966) Allocative Efficiency vs. "X-Efficiency". American Economic Review, 56, 392-415.

[35] Lin, C., Ma, Y. and Su, D. (2009) Corporate Governance and Firm Efficiency: Evidence from China's Publicly Listed Firms. Managerial and Decision Economics, 30, 193-209. http://dx.doi.org/10.1002/mde.1447 
[36] The Property Bank (2014) State-Owned Enterprise Governance Coordination Unit. StateOwned Enterprises.

[37] OECD (2015) OECD Guidelines on Corporate Governance of State-Owned Enterprises. OECD Publications, Paris.

[38] Simar, L. and Wilson, P.W. (2007) Estimation and Inference in Two-Stage, Semi-Parametric Models of Production Processes. Journal of Econometrics, 136, 31-64. http://dx.doi.org/10.1016/j.jeconom.2005.07.009

[39] Korostelev, A., Simar, L. and Tsybakov, A. (1995) Efficient Estimation of Monotone Boundaries. The Annals of Statistics, 23, 476-489. http://dx.doi.org/10.1214/aos/1176324531

[40] Park, B.U., Jeong, S.O. and Simar, L. (2010) Asymptotic Distribution of Conical-Hull Estimators of Directional Edges. The Annals of Statistics, 38, 1320-1340. http://dx.doi.org/10.1214/09-AOS746

[41] Debreu, G. (1951) The Coefficient of Resource Utilization. Econometrica, 19, 273-292. http://dx.doi.org/10.2307/1906814

[42] Farrell, M.J. (1957) The Measurement of Productive Efficiency. Journal of the Royal Statistical Society, 120, 253-290. http://dx.doi.org/10.2307/2343100

[43] Shephard, R.W. (1970) Theory of Cost and Production Functions. The Journal of Economic History, 31, 721-723. 


\section{Appendix: Lithuanian SOE Corporate Governance Index Assessment Criteria}

\begin{tabular}{|c|c|c|}
\hline Category & Assessment Criteria & Description \\
\hline \multirow{4}{*}{ Transparency } & $\begin{array}{l}\text { Comprehensiveness of the } \\
\text { SOE summary reports }\end{array}$ & $\begin{array}{l}\text { Level of comprehensiveness and publicity of annual reports of each SOE, as stated in the requirements } \\
\text { of Transparency guidelines. }\end{array}$ \\
\hline & SOE social responsibility & $\begin{array}{l}\text { SOE social reasonability, assessed on the basis of two criteria: comprehensiveness of information on } \\
\text { implemented social and environmental initiatives provided in the enterprises' activity reports or annual } \\
\text { reports, and whether enterprises have separate CSR reports in place. }\end{array}$ \\
\hline & $\begin{array}{l}\text { International accounting } \\
\text { standards (IAS) }\end{array}$ & $\begin{array}{l}\text { Application of IAS, allowing greater comparability on international level and decreasing differences in } \\
\text { accounting practices, by each enterprise. }\end{array}$ \\
\hline & Opinion of external auditors & $\begin{array}{l}\text { Evaluated on the basis of two criteria: opinion of external auditors on the SOE financial statements, and } \\
\text { how often each enterprise changed their independent auditor in the last seven years. }\end{array}$ \\
\hline \multirow{6}{*}{ Boards } & Board independency & $\begin{array}{l}\text { Two criteria: the number of independent members on company boards (independent members should } \\
\text { comprise one third or more of the total number of board members) and the number of board members } \\
\text { not taking part in sector policy making. }\end{array}$ \\
\hline & Board competences & $\begin{array}{l}\text { As indicated in Ownership guidelines, each company board should include members with competences } \\
\text { in the fields of finance, strategic planning and the relevant sector, in ideal case, acquired in the private } \\
\text { sector. }\end{array}$ \\
\hline & $\begin{array}{l}\text { Sitting of SOE } \\
\text { employees on the boards }\end{array}$ & $\begin{array}{l}\text { Presence of SOE employees on the boards. Disadvantageous, as it reduces board's independence from } \\
\text { company's management. }\end{array}$ \\
\hline & $\begin{array}{l}\text { Board members' } \\
\text { participation }\end{array}$ & $\begin{array}{l}\text { Assessed on two criteria: whether SOE board members sit on boards of more than three other } \\
\text { companies (consider disadvantageous, as such board member is unlikely to devote sufficient } \\
\text { time and attention to company's problems), and the frequency of board meetings. }\end{array}$ \\
\hline & Board committees & Evaluates if Audit and Remuneration committees are formed at each enterprise. \\
\hline & $\begin{array}{l}\text { Selection of board } \\
\text { members }\end{array}$ & $\begin{array}{l}\text { Assessment of board member selection criteria. Presence of Selection committee and utilization of } \\
\text { open selection procedures for appointing board members evaluated as good practices. }\end{array}$ \\
\hline \multirow{3}{*}{$\begin{array}{c}\text { Strategic } \\
\text { planning, } \\
\text { strategic } \\
\text { implementation } \\
\text { and control }\end{array}$} & $\begin{array}{c}\text { Quality of corporate } \\
\text { strategies }\end{array}$ & Evaluation of SOE corporate strategies carried out by Governance Coordination Center. \\
\hline & $\begin{array}{l}\text { Supervision of strategy } \\
\text { implementation and } \\
\text { internal control system }\end{array}$ & $\begin{array}{l}\text { Assessment criteria: presence of strategy implementation procedure in internal documents of SOE; fully } \\
\text { or partially operation internal control system and control procedures, especially related to risk factor } \\
\text { management; internal periodic audits. }\end{array}$ \\
\hline & $\begin{array}{l}\text { Implementation of } \\
\text { corporate objectives }\end{array}$ & $\begin{array}{l}\text { Assessment of fulfillment of SOE objectives, according to the goals set by the State: } 1 \text { ) } \bullet \text { Annual ROE at } \\
\text { least } 5 \% \text { for Group } 1 \mathrm{~A} \text { and } 1 \mathrm{~B} \text { enterprises (except forestry companies which have individual profit } \\
\text { targets); 2) Positive ROE for Group } 2 \text { enterprises. }\end{array}$ \\
\hline
\end{tabular}


Submit or recommend next manuscript to SCIRP and we will provide best service for you:

Accepting pre-submission inquiries through Email, Facebook, LinkedIn, Twitter, etc.

A wide selection of journals (inclusive of 9 subjects, more than 200 journals)

Providing 24-hour high-quality service

User-friendly online submission system

Fair and swift peer-review system

Efficient typesetting and proofreading procedure

Display of the result of downloads and visits, as well as the number of cited articles

Maximum dissemination of your research work

Submit your manuscript at: http://papersubmission.scirp.org/

Or contact me@scirp.org 